\title{
Ergonomic analysis of the work conditions of porters and owners of the Supply Center of Campinas, $\mathrm{SP}^{1}$
}

\author{
Tatiana Giovanelli Vedovato ${ }^{\mathrm{a}^{*}}$, Maria Inës Monteiro ${ }^{\mathrm{a}}$, Valéria Aparecida Masson ${ }^{\mathrm{a}}$ \\ ${ }^{a}$ Faculty of Medical Sciences, State University of Campinas-UNICAMP,Campinas, Brazil.
}

\begin{abstract}
Transforming work conditions is part of the ergonomic action that should help to improve work situations that brings risks to the workers health. six workers were observed in different locations of the supply center (Central Free Market, Free Market 2, Flowers Market and Permanent Shed 4). During the observation of workers to the Ergonomic Analysis of Work - AET (Rohmert and Landau) was performed. The workers were divided into two groups: porters and owners. The porters were the most susceptible to the risks of work and minor accidents with sharp wood from boxes or even risk of traffic accidents as pedestrians. However, regarding the use of mental ability for negotiations, use of computers and organizing and planning the establishment of work, the owners were the ones that most time played these activities. The ergonomics advocates work that can be transformed and that favors employee and employer. It is, therefore, intended to redefine the strategies that are embedded into the organizational structure of work.
\end{abstract}

Keywords: Occupational Health; Occupational Health Policy; Human Engineering

\section{Introduction}

The ergonomic action has purpose for the transformation of work for welfare worker. Transforming work conditions is part of the ergonomic action that should help to improve work situations that brings risks to the workers health [3]. Thus, ergonomics became an important tool in any production process or any product that has direct contact with the man.

Ergonomic Analysis of Work (AET) is the main tool of the Activity-centered ergonomic intervention. It can help to solve several problems related to working conditions or the design of tools and equipment [2].

The Supply Center of Campinas, São Paulo (CEASA), is constituted by more than 1,000 micro and small sized companies, including shops, surveil- lance and cleaning services, administrative sector and autonomous porters.

Through the research project of public policies entitled "Basis for the implementation of worker's health public service in informal work and SMEs of Wholesale and Flower Market in São Paulo State Brazil" [5], diagnosis was made on the status of site and suggested activities to promote health at work. A sample of 1,006 workers, being mostly men (86.9\%) aged between 15 and 73 years (average 33.5 years $\mathrm{SD}=12.1$ ) took part in the research [3]. The ergonomic analysis is one of the stages of this public policies research project. Thus the aim of this study was to perform an ergonomic analysis of work with six workers from the CEASA.

The aim of this study was to analyze real work situation (physical and organizational environment) and to identify possible ergonomic risks through the er-

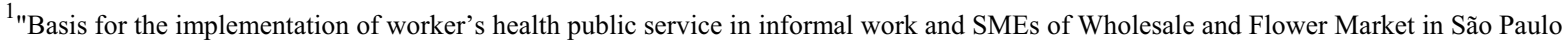
State - Brazil".

${ }^{*}$ Corresponding author: Rua Presidente Bernardes, 1293 apto 13. CEP 13091-160 Campinas - SP Email: tatigio@fcm.unicamp.br

Fone: (19) 35218820
} 
gonomic analysis of the work among porters and owners.

\section{Methods}

It was observed during the month of July 2007 six workers for five consecutive hours of work in different locations on site supply center of Campinas (Central Free Market, Free Market 2, Flowers Market and Permanent Shed 4).

Among these employees, two owners were stone free markets, one male and one female, and a store owner (Box) in Shed Permanent and three were porters, being one autonomous and two employees, all three males. During the observation of these workers for data collection, an ergonomic analysis of the work (AET) has been performed using the instrument Rohmert and Landau [7], which describes physical and organizational working environment aspects.

The method of ergonomic analysis of work, as described by Guerin, allows an assessment of the status of work on aspects of the environment, from the position, equipment, organization and psychosocial factors, aiming to transform the work so that workers can perform their tasks without affecting their health [3].

The AET provides five steps: demand analysis, task analysis, activity analysis, work behaviors, diagnosis and recommendations [3].
The ergonomic data analysis was performed using the Excel ${ }^{\circledR}$ program and the results were presented graphically. The study was approved by the Ethics Committee of the Faculty of Medical Sciences State University of Campinas - Unicamp.

\section{Results}

The workplace environment was opened, cemented floor with the presence of noise and exhaust smokes of vehicles due to the constant flow of cars and trucks. The lighting in part of the workday that began at dawn was inadequate. The workers were divided into two groups: porters and owners.

Some variables such as work force / heavy active movement, walking by the CEASA area, manual work and work with equipment (hand cart) were observed during all the time (five hours) in contact with porters.

The contact with others was considered a piece of work both for porters and owners. The porters were the most susceptible to the risks of work and minor accidents with sharp wood from boxes or even risk of traffic accidents as pedestrians (figure 1). However, regarding the use of mental ability for negotiations, use of computers and organizing and planning the establishment of work, the owners were the ones that most time played these activities (Figure 2). 
Work force / heavy active movement

Dynamic work

Walking by the CEASA area

Manual work

范

Curved body posture

Standing body posture

Sittingbody posture

Demand visual / hearing

Work with equipment

Workplace environment

Organization/planning
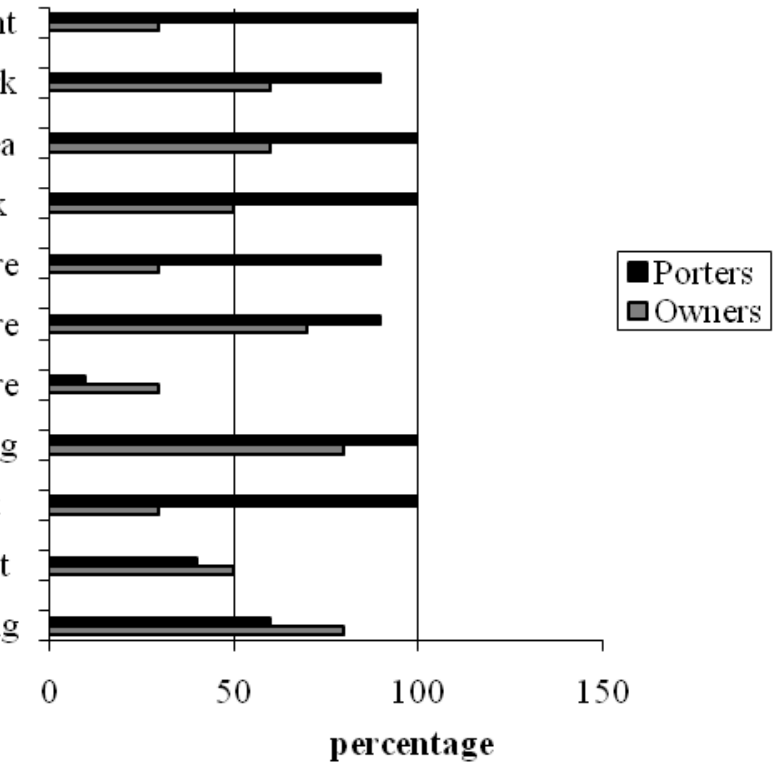

Figure 1 - Ergonomic analysis of the work (AET) conditions of porters and owners of the Supply Center of Campinas, SP

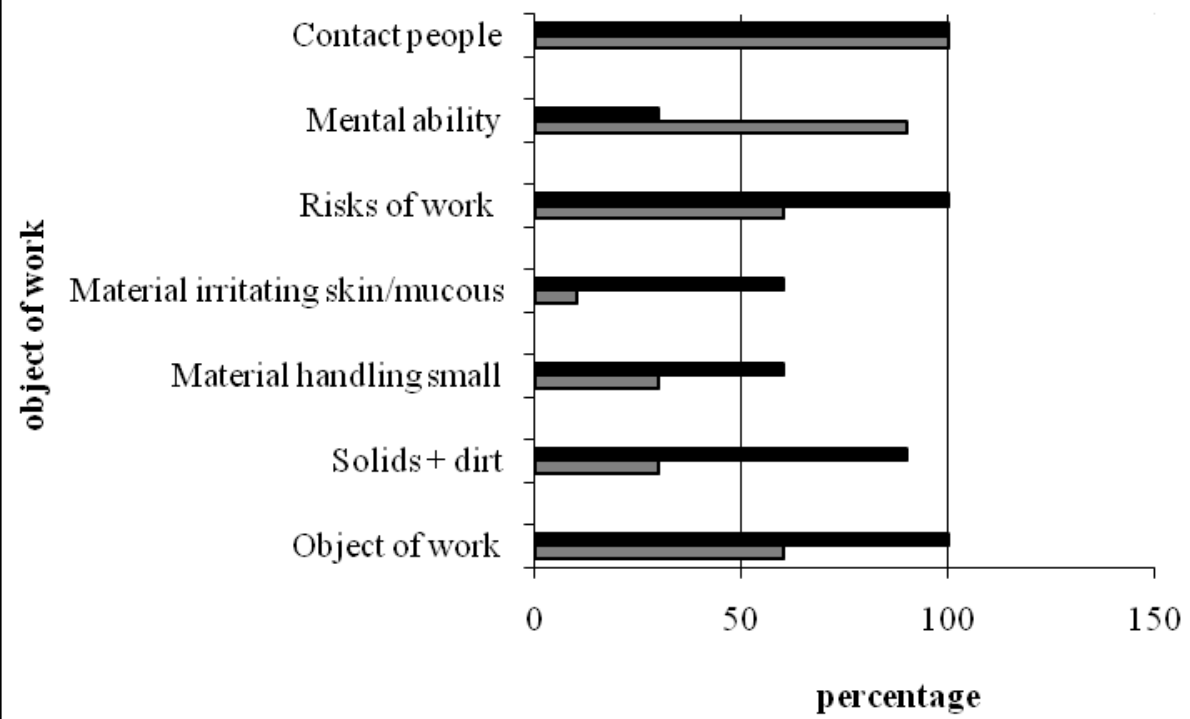

- Porters

口Owners

Figure 2 - Ergonomic analysis of the work (AET) conditions of porters and owners of the Supply Center of Campinas, SP 


\section{Discussion}

The observations of ergonomic conditions for the work day always started at dawn, around five o'clock in the morning, and workers used to arrive at CEASA about four o'clock in the morning. Night shifts can lead to significant effects on the worker's health, with a rapid individual wear due to disturbs in biological rhythms; often hard to adapt, and affect social and family life [4].

The equipment used in the work of the group of porters were wooden hand carts operated by human impulse and plastic and wooden boxes, loaded with products - approximately $25 \mathrm{~kg}$ per box, which requires great physical effort of these workers.

The manual handling of loads, the weight limit recommended by the National Institute for Occupational Safety and Health (NIOSH) is $23 \mathrm{~kg}$. The weight of the load handled by these porters is superior or very close to this limit [6].

The equipment used by the owners was blocks of paper and pen, and the computer in some places, requiring greater mental demands. The workers who performed tasks with greater mental load, also complained about physical pains, such as low back pain and cervical pain, and stress and fatigue [1]. In general, markets in the area of each stone, about $8 \mathrm{~m}^{2}$, were relatively small, and there were no objects for workers to sit down, which led to improvisation of the seats.

In Brazil, the worker health system is structured only for the formal market, thus creating a gap on the provision of health care service for informal workers. This issue is even more aggravated in large workplaces, such as Wholesale and Flower Market (CEASA-Campinas) [5]. Therefore, the observation of ergonomic conditions in the workplace can contribute to the health promotion.

\section{Conclusion}

Ergonomics advocates work that can be transformed and that favors employee and employer. It is, therefore, intended to redefine the strategies that are embedded into the organizational structure of work.

The ergonomic analysis of work is a tool of great importance to the occupational health because it provides data for actions to improve the working conditions, disease prevention and health promotion of the workers.

\section{References}

[1] A. Moraes, C. Mont'alvão. Ergonomia: conceitos e aplicações. Rio de Janeiro: 2AB; 2002.

[2] A. Wisner. Por dentro do trabalho Egonomia: Método \&Técnica. São Paulo:FDT: Oboré, 1987.

[3] F. Guérin , A. Laville , F.Daniellou et al. Compreender o trabalho para transformá-lo: a prática da ergonomia. São Paulo:Editora Edgard Blucher Ltda,2001

[4] J. Rutenfranz, P. Knauth, F.M. Fischer. Trabalho em turnos e noturno. São Paulo: Hucitec; 1989.

[5] M.I. Monteiro, K. Tuomi,J. Ilmarinen, E Tuominen, J. Seitsamo , H. Corrêa-Filho. WAI among workers is SMEs at Wholesale, Fruits vegetables and flower market in Brazil. In: Masaharu Kumashiro. (Org.). Promotion of work ability towards productive aging. London: Taylor \& Francis, 2009, p. 37-40.

[6] T.R. Walters, et al. revised NIOSH for design and evaluation of manual lifting tasks. Ergonomics. 1993;36(7):749-76

[7] W. Rohmert, K. Landau. A new technique for job analysis. London and New York: Taylor \& Francis Ltd. 1983. 93p. 